\title{
Traveller's diarrhoea with a vengeance in children of UK immigrants visiting their parental homeland
}

\author{
PAUL HUTCHINS, PRAEV HINDOCHA, ALAN PHILLIPS, AND JOHN WALKER-SMITH \\ Queen Elizabeth Hospital for Children, London
}

SUMMARY Six healthy children, born in the UK, travelled to their parental homeland and developed a severe form of traveller's diarrhoea. This was characterised by rapid loss of weight and chronic diarrhoea. On return to this country, investigation in 5 of them showed an abnormal, small intestinal mucosa. There was a high incidence of pathogens and potential pathogens found in stools and duodenal juice. Immunodeficiency was found in 2 of them. Small intestinal mucosal damage related to gut infection in previously well children appears to be of cardinal importance in the interaction between chronic diarrhoea and malnutrition. This observation may point the way to future research into the primary role of gut infection in the initiation of the cycle of malnutrition and chronic diarrhoea in developing communities.

In many countries, chronic diarrhoea and malnutrition interact to provide a major cause of death and severe illness in childhood. In Britain such interaction is rarely seen; yet recently at this hospital we have encountered a number of healthy young children, born in Britain, who became severely ill when they first visited their parental homeland. Acute diarrhoea became persistent and was accompanied by rapid weight loss.

In view of the children's previous good health and nutrition this experience is relevant to the interaction between nutrition and gastrointestinal infection in childhood. ${ }^{1}$

\section{Case histories}

Between September 1978 and July 1979, six boys aged between 6 and 35 months, born in England but taken for a first visit to their parents' country of birth, were admitted to this hospital with severe chronic diarrhoea. They had visited the Indian subcontinent or Morocco. Before departure all had a history of good health, adequate nutrition, and normal growth. This was corroborated, if possible, by child health centre records or inferred from recent family photographs. Details of individual children are shown in Table 1.

Table 1 Clinical features and treatment

\begin{tabular}{|c|c|c|c|c|c|c|c|}
\hline Case & $\begin{array}{l}\text { Age at admission } \\
\text { (months) }\end{array}$ & Country & $\begin{array}{l}\text { Duration } \\
\text { of visit } \\
\text { (weeks) }\end{array}$ & $\begin{array}{l}\text { How soon } \\
\text { after arrival } \\
\text { did symptoms } \\
\text { start (weeks) }\end{array}$ & $\begin{array}{l}\text { Time between } \\
\text { return to UK } \\
\text { and admission }\end{array}$ & $\begin{array}{l}\text { Condition on } \\
\text { admission }\end{array}$ & Treatment \\
\hline 1 & 6 & Pakistan & 12 & 2 & 4 days & $\begin{array}{l}8-10 \% \text { dehydrated, } \\
10 \text { stools daily }\end{array}$ & $\begin{array}{l}\text { Parenteral alimentation for } 6 \\
\text { weeks. Cows' milk protein- } \\
\text { free diet for one year }\end{array}$ \\
\hline 2 & 8 & Pakistan & 8 & 3 & 2 days & 10 stools daily & $\begin{array}{l}\text { Intravenous fluids for } 2 \text { days } \\
\text { then graded slowly to } \\
\text { normal diet }\end{array}$ \\
\hline 3 & 12 & Morocco & 5 & 2 & 12 hours & $\begin{array}{l}7 \% \text { dehydrated, } \\
\text { pyrexia, abdominal } \\
\text { pain, } 9 \text { stools daily }\end{array}$ & $\begin{array}{l}\text { Parenteral alimentation for } 10 \\
\text { days then graded slowly to } \\
\text { normal diet }\end{array}$ \\
\hline 4 & 18 & Pakistan & 20 & 1 & 3 days & Pyrexia, 6 stools daily & Metronidazole $500 \mathrm{mg}$ daily $\times 6$ \\
\hline 5 & 23 & India & 10 & 3 & 2 weeks & $\begin{array}{l}\text { Pyrexia, fever, } \\
10 \text { stools daily }\end{array}$ & $\begin{array}{l}\text { Parenteral alimentation for } 6 \\
\text { weeks. Multiple antibiotics } \\
\text { then graded slowly to normal } \\
\text { diet after } 3 \text { months }\end{array}$ \\
\hline 6 & 35 & India & 10 & 6 & 5 days & $\begin{array}{l}\text { Abdominal distension, } \\
5 \text { stools daily }\end{array}$ & $\begin{array}{l}\text { Intravenous fluids } 3 \text { days. } \\
\text { Metronidazole } 800 \mathrm{mg} \text { daily } \\
\times 3 \text { then graded slowly to } \\
\text { normal diet }\end{array}$ \\
\hline
\end{tabular}


Most of the children were symptomatic within 3 weeks of arrival abroad. All had diarrhoea of acute onset, sometimes accompanied by fever and vomiting. The initial illness did not appear remarkable for the countries they visited, but the symptoms became persistent and the children lost weight. On admission 5 of them were below the 3rd centile for weight. Each was admitted to this hospital within hours or days of his return to England, except for Cases 1 and 5 who were referred from other hospitals. In all, the presenting symptom was chronic diarrhoea which had persisted from the initial illness. No specific details of treatment abroad were given, other than vague histories of 'infection', 'clear fluids' in three (Cases 2, 4, and 5). No child had brought medical records from abroad.

Each child was investigated and treated as intensively as his clinical condition warranted. The principles of management were to proceed from a glucose electrolyte mixture, regrading to a normal diet, or to use intravenous fluid if dehydration and severity of diarrhoea so indicated (Table 1). Three children were so malnourished and diarrhoea so intractable that parenteral alimentation was used.

Laboratory investigations relating to small intestinal histology, stool microbiology, immunological function, and relevant haematology and biochemistry are listed in Table 2 . In all but one child, small intestinal mucosa was obtained by peroral paediatric double port Crosby capsule.

In all children stools were cultured for bacterial pathogens and viruses, examined for the presence of parasites, and studied with the electron microscope for viral particles. At the time of small intestinal mucosal biopsy, duodenal juice was examined microscopically for the presence of parasites such as Giardia lamblia (Table 2).

Small intestinal biopsy demonstrated an enteropathy in all cases biopsied (Figs 1 and 2). The mucosal damage was particularly severe in children (Cases 1 and 5) in whom the weight loss was profound and who also had a very low serum albumin level. It was especially severe in Case 5 who showed Escherichia coli adherent to damaged enterocytes on electron microscopy. Two children showed a temporary impairment of T-cell lymphocyte transformation with phytohaemagglutinin. One of these had persistent IgG and IgA hypogammaglobulinaemia, with a temporary neutropenia and impaired opsonisation. All children

Table 2 Laboratory investigations

\begin{tabular}{|c|c|c|c|c|}
\hline Case & $\begin{array}{l}\text { Histology of small } \\
\text { intestinal mucosa }\end{array}$ & $\begin{array}{l}\text { Microbiology of stool and } \\
\text { duodenal juice (as indicated) }\end{array}$ & $\begin{array}{l}\text { Immunological studies serum } \\
\text { immunoglobulins }(I U / \mathrm{ml})\end{array}$ & $\begin{array}{l}\text { Haematology and biochemistry } \\
\text { on admission }\end{array}$ \\
\hline 1 & $\begin{array}{l}\text { Patchy severe enteropathy, } \\
\text { IEL 27. Disacchardidases } \\
\text { all low } \\
\text { Normal mucosa } 3 \text { weeks later }\end{array}$ & E. coli O114. Adenovirus sp. & $\begin{array}{l}\text { IgG } 74 \text { normal. } \\
\text { IgA } 24 \text { normal. } \\
\text { IgM } 147 \text { high normal. } \\
\text { Opsonisation normal. } \\
\text { T-cell transformation } \\
\text { impaired for } 3 \text { weeks }\end{array}$ & $\begin{array}{l}\mathrm{Hb} 11 \cdot 3 \mathrm{~g} / \mathrm{dl} \text {. } \\
\text { Indices normal. } \\
\text { Serum protein } 45 \mathrm{~g} / 1 \text {, } \\
\text { albumin } 26 \mathrm{~g} / 1 \text {, } \\
\text { serum iron normal }\end{array}$ \\
\hline 2 & $\begin{array}{l}\text { Mild enteropathy, IEL } 50 . \\
\text { Disaccharidases all low }\end{array}$ & $\begin{array}{l}\text { E. coli } 086 \\
\text { E. coli } \mathrm{O} 128 \\
\text { Candida } \mathrm{sp} .\end{array}$ & & $\begin{array}{l}\text { Hb } 10 \mathrm{~g} / \mathrm{dl} \text {, serum protein } \\
70 \mathrm{~g} / \mathrm{dl} \text {, albumin } 36 \mathrm{~g} / \mathrm{l}, \\
\text { serum iron low, TIBC high, } \\
\text { saturation low }\end{array}$ \\
\hline 3 & No biopsy performed & $\begin{array}{l}\text { Shigella flexneri 4B } \\
\text { E. coli } \mathrm{O} 111 \\
\text { E. coli } \mathrm{O} 142 \\
\text { Campylobacter sp. } \\
\text { Candida sp. }\end{array}$ & $\begin{array}{l}\text { IgG } 123 \text { high normal. } \\
\text { IgA } 93 \text { high. } \\
\text { IgM } 120 \text { normal. }\end{array}$ & $\begin{array}{l}\mathrm{Hb} 12 \mathrm{~g} / \mathrm{dl} \text {, serum protein } \\
48 \mathrm{~g} / \mathrm{l} \text {, albumin } 21 \mathrm{~g} / \mathrm{l} \\
\text { serum iron low }\end{array}$ \\
\hline 4 & Mild enteropathy, IEL 50 & $\begin{array}{l}\text { Pentatrichomonas hominis } \\
\text { trophozoites }\end{array}$ & $\begin{array}{l}\text { IgG } 188 \text { high. } \\
\text { IgA } 54 \text { normal. } \\
\text { IgM } 141 \text { normal. }\end{array}$ & $\begin{array}{l}\text { Hb } 11.6 \mathrm{~g} / \mathrm{dl} \text {, serum protein } \\
41 \mathrm{~g} / \mathrm{l} \text {, albumin } 33 \mathrm{~g} / \mathrm{l}, \\
\text { serum iron low }\end{array}$ \\
\hline 5 & $\begin{array}{l}\text { (1) Severe enteropathy, } \\
\text { IEL } 12 \text {. Disaccharidases } \\
\text { all low. } \\
\text { (2) } 5 \text { weeks later, normal } \\
\text { mucosa. } \\
\text { (3) } 1 \text { year later, normal } \\
\text { mucosa }\end{array}$ & $\begin{array}{l}\text { Pseudomonas aeruginosa for } 8 \\
\text { weeks. E. coli } \mathrm{O} 128 \text { for } 6 \\
\text { weeks. Klebsiella sp. } \\
\text { (1) Duodenal juice } \\
\text { Pseudomonas aeruginosa } \\
2 \times 10^{5} \text { org } / \mathrm{ml}, E \text {. coli: } \\
\text { O128 } 1 \times 10^{5} \text { org } / \mathrm{ml} \text {. } \\
\text { (2) Duodenal juice sterile }\end{array}$ & $\begin{array}{l}\text { IgG } 10 \text { very low. } \\
\text { IgA } 8 \text { very low. } \\
\text { IgM } 340 \text { very low. } \\
\text { Neutropenia } \\
\text { Low } \\
\text { opsonisation }\} \text { for } 3 \text { weeks } \\
\text { T-cell transformation } \\
\text { impaired for } 5 \text { weeks. } \\
\text { For at least } 2 \text { years persistent } \\
\text { unrecordable levels of IgG } \\
\text { and IgA }\end{array}$ & $\begin{array}{l}\text { After one blood transfusion: } \\
\mathrm{Hb} 9 \mathrm{~g} / \mathrm{dl} \text {, serum protein } \\
35 \mathrm{~g} / \mathrm{l} \text {, albumin } 20 \mathrm{~g} / \mathrm{l} \\
\text { serum iron low }\end{array}$ \\
\hline 6 & $\begin{array}{l}\text { Mild enteropathy, IEL } 48 . \\
\text { Low lactase activity. } \\
\text { Other disaccharidases } \\
\text { normal }\end{array}$ & $\begin{array}{l}\text { No stool pathogens. } \\
\text { Duodenal juice (after } \\
\text { treatment) yeasts only }\end{array}$ & $\begin{array}{l}\text { Serum IgG } 168 \text { high normal. } \\
\text { IgA } 72 \text { normal. } \\
\text { IgM } 192 \text { high normal. } \\
\text { G. lamblia fluorescent antibody } \\
\text { titres positive } 1 / 60\end{array}$ & $\begin{array}{l}\mathrm{Hb} 12 \mathrm{~g} / \mathrm{dl} \text {, protein } 61 \mathrm{~g} / \mathrm{l} \text {, } \\
\text { albumin } 37 \mathrm{~g} / \mathrm{l}\end{array}$ \\
\hline
\end{tabular}

IEL $=$ intraepithelial lymphocytes per 100 epithelial cells. 
gained weight after treatment. The 4 children whose weight centiles were known before departure from the UK recovered to at least this centile after treatment, most of them within a few weeks. Times of follow-up varied, but where possible growth was monitored over months and growth rates have been maintained (Table 3).

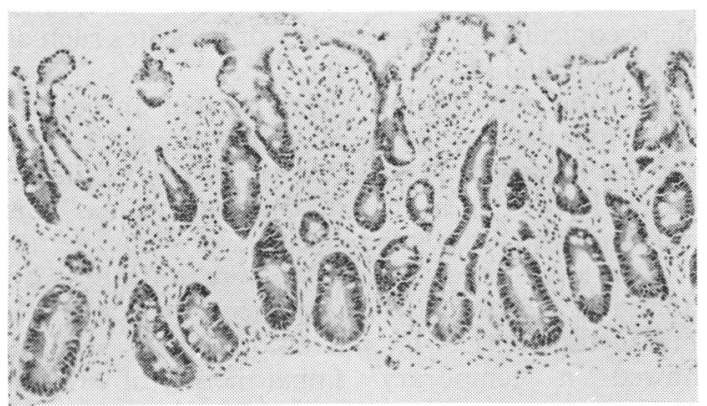

Fig. 1 (Case 5.) Small intestinal biopsy showing severe villous atrophy with crypt hypertrophy. $\times 80$.

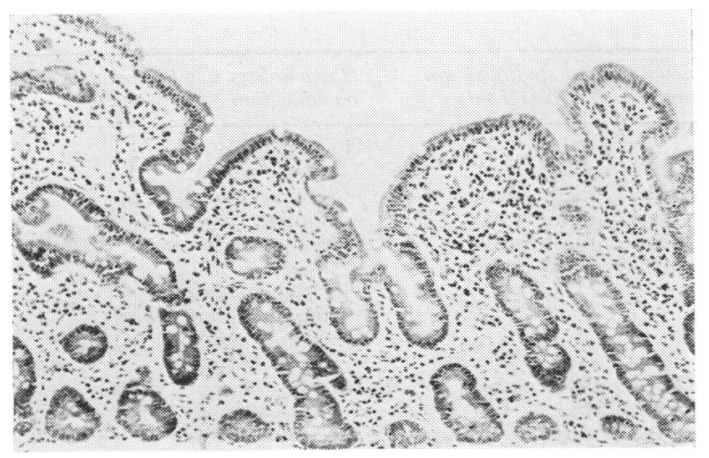

Fig. 2 (Case 6.) Small intestinal biopsy. Villous atrophy with crypt hypertrophy. $\times 80$.

\section{Discussion}

The children described here presented a clinical picture of chronic diarrhoea and malnutrition all too familiar in much of the world, but rare in the UK. They suffered persistent diarrhoea and a strikingly rapid loss of weight. Unlike many children in countries where diarrhoeal disease contributes so much to death and morbidity, these children had enjoyed good health since birth in England until their acute illness while abroad. Yet once diarrhoea became persistent, the children markedly lost weight and the severity of the illness on presentation in London was surprising in view of their previous wellbeing. Why then did they become so ill?

Acute diarrhoea within a short time of arrival abroad is referred to as traveller's diarrhoea and it classically involves affliction with previously unencountered pathogens. ${ }^{2}$ Both food and water may contain many pathogens ${ }^{3}$ and in these children's parental homelands both could offer a source of large numbers of previously unencountered organisms compared with food and water consumed in England.

In view of the good health of the children before their journey abroad we must assume that infection played a key role in determining the clinical severity of the illness and that the diagnosis was a particularly severe form of traveller's diarrhoea. However, subsequent anorexia with resulting poor food intake and also limited medical treatment may have played a role, albeit secondary. Traveller's diarrhoea is typically a self-limiting illness, yet the mean duration of symptoms before admission was $\mathbf{9 . 2}$ weeks.

This persistence may be explained in turn by persistent infection, persistent small intestinal mucosal damage (that is enteropathy), and by immunodeficiency which could be age related, as 5 of the children were under age 2 years.

The severity of the illness in Case 6 with presumed giardiasis and a mild enteropathy may relate to infestation with this parasite as prolonged symptoms

Table 3 Details of height and weight centiles

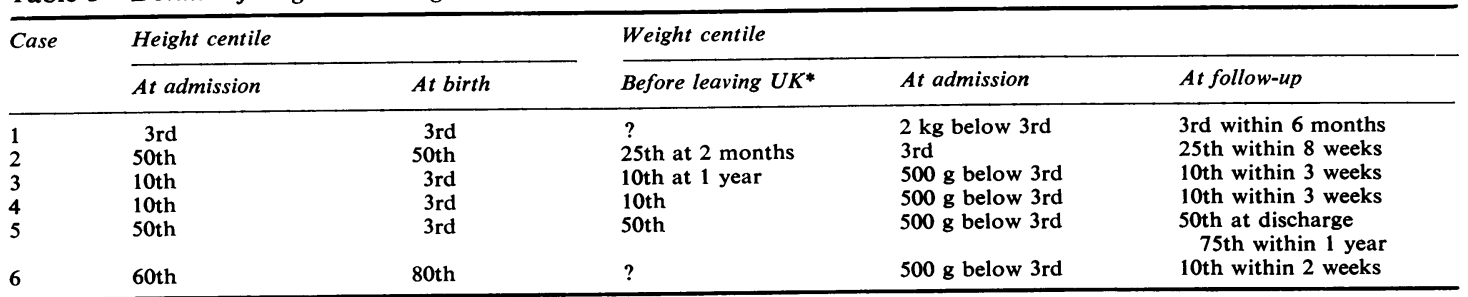

*Last known weight. 
in traveller's diarrhoea due to G. lamblia are well known, sometimes with rapid weight loss. ${ }^{45} \mathrm{~A}$ similar explanation may exist for Case 4, a child infected with the protozoan flagellate, Pentatrichomonas hominis. However, it is largely a colonic parasite and the presence of a small intestinal enteropathy may be of more importance in explaining the child's illness. The remaining 4 children, who had a mean duration of symptoms of 7 weeks, required intravenous fluids on admission, 3 in turn requiring subsequent parenteral alimentation. All had mixed infections with known strains of enteropathogenic $E$. coli in their stools plus recognised or possible pathogenic organisms.

For all children, daily stool samples were cultured. In Cases 2, 3, 4, and 5 the disappearance of the possible pathogens quoted in Table 2 and the stopping of diarrhoea were separated by no longer than 3 days. In Case 6, treatment with met_ onidazole was started without examining duodenal juice for presence of $G$. lamblia. The diarrhoea stopped within 2 days and there was serological evidence consistent with giardiasis. In Case 1 an enteropathogenic strain of $E$. coli had been consistently demonstrated in the referring hospital and his clinical course reflected the existence of an enteropathy. When treatment was given (Table 1) the condition of all children soon improved (Table 3). The concordance between clinical recovery and the disappearance of organisms from stool cultures supports a pathogenic role for at least some of the potential pathogens found in the stools.

In the individual affected child, it is difficult to ascribe symptoms to one particular organism among possible pathogens, and the multiplicity of organisms may be important in the severity of these children's illnesses. Mixed infections are rare in our experience but if they do occur may be associated with more severe clinical disease. ${ }^{6}$

The presence of small intestinal mucosal damage in all children biopsied, perhaps as a direct result of infection, may be of more importance. The most severe lesions were in those with the most pronounced weight losses and the lowest serum albumin levels. Was this enteropathy then a postenteritis enteropathy and its persistence of critical importance in the severity of the children's illness? The relationship of this enteropathy to the abnormal bacterial flora is not certain, although in Case 5 the adhesion of $E$. coli $\mathrm{O} 128$ to damaged enterocytes would appear to be important aetiologically. High dosage and continuing exposure to bacterial pathogens may also be important. There was complete healing of the small intestinal mucosa in the 2 patients who had the most severe enteropathy at the time that they had clinically recovered, were taking a normal diet, and the infections had cleared from stool cultures.

Immunodeficiency was found in 2 children (Cases 1 and 5). Serum immunoglobulins were normal or raised in all except Case 5, who had low IgA and IgG levels. These have persisted for 2 years. If this hypogammaglobulinaemia were congenital, it is surprising that he remained so healthy as an infant. $\mathrm{He}$ and Case 1 had temporary evidence of T-cell dysfunction, as has been described in 5 of 27 severely malnourised children. ${ }^{7}$ The significance of these findings in these 2 children in relation to the whole illness is unclear, but it is possible that the enteropathy in some way has affected local immune function in the gut and even systemically, and thus played a part in the persistence of bacterial pathogens and in the enteropathy itself.

The microbiological findings and the small intestinal enteropathies found in these children, plus their previous good health and nutrition, suggest that persistent small intestinal mucosal damage related to gut infection may be of primary importance in the interaction between chronic diarrhoea and malnutrition in these children. Such infection may also have initiated the cycle of chronic diarrhoea, malnutrition, and small intestinal damage in countless more children living in developing communities. This observation stresses the need for research into the possible primary role of gut infection in such circumstances.

On a practical note, immigrant parents of UKborn infants should give some thought to the potential health hazards in taking children, especially those under 2 years, to their ancestral homeland.

\section{References}

1 Feigen R D. Interaction of nutrition and infection: plans for future research. Am J Clin Nutr 1977; 30: 1553-63.

2 Turner A C. The diarrhoeas of travel. Br J Hosp Med 1977; 17: 22-31.

3 Barrell R A E, Rowland M G M. The relationship between rainfall and well water pollution in a West African (Gambian) village. J Hyg (Camb) 1979; 83: 143-50.

4 Eastham E J, Douglas A P, Watson A J. Diagnosis of Giardia lamblia infection as a cause of diarrhoea. Lancet 1976; ii: 950-1.

5 Brandborg L L, Owen R, Fogel R, et al. Giardiasis and traveler's diarrhea. Gastroenterology 1980; 78: 1602-14.

- Shepherd R W, Truslow S, Walker-Smith J A, et al. Infantile gastroenteritis: a clinical study of reovirus-like agent infection. Lancet 1975 ; ii: $1082-4$.

7 Neumann C G, Lawlor G J, Jr, Stiehm E R, et al. Immunologic responses in malnourished children. Am J Clin Nutr 1975; 28 : 89-104.

Correspondence to Dr J A Walker-Smith, Queen Elizabeth Hospital for Children, Hackney Road, London E2 8PS.

Received 14 April 1981 